\title{
Ceradenia itatiaiensis, a New Species of Polypodiaceae from Southeastern Brazil
}

\author{
Paulo Henrique Labiak \\ Universidade Federal do Paraná, Departamento de Botânica, Caixa Postal 19031, Curitiba, PR \\ 81531-980,Brazil.plabiak@ufpr.br
}

João Paulo S. Condack

Instituto de Pesquisas, Jardim Botânico do Rio de Janeiro, Rua Pacheco Leão 915, Rio de Janeiro, RJ 22460-030, Brazil. jpcondack@gmail.com

ABSTRACT. Recent collections of Polypodiaceae in Brazil reveal a new species of Ceradenia L. E. Bishop, C. itatiaiensis Labiak \& Condack, that appears to be a narrow endemic to the Itatiaia National Park. It resembles $C$. albidula (Baker) L. E. Bishop, but differs mainly by having setae on the laminar margins. Descriptions and illustrations are provided, as well as comments on the most closely related species.

Key words: Brazil, Ceradenia, grammitid ferns, Itatiaia, IUCN Red List, Polypodiaceae.

Ceradenia L. E. Bishop is primarily a Neotropical genus of Polypodiaceae, with about 60 species occurring on mountains of Central and South America, and with eight species also present in Africa, Madagascar, and/or the Azores (Bishop, 1988; Parris, 2002, 2005). Parris (2002) made combinations for six species of Ceradenia in Africa, and there are at least two others known: C. jungermannioides (Klotzsch) L. E. Bishop and C. pruinosa (Maxon) L. E. Bishop, both species also occurring in the Neotropics. The genus is monophyletic according to the phylogenies presented by Ranker et al. (2004) and is defined mainly by the glandular paraphyses in the sori and by the absence of hydathodes.

A taxonomic treatment for six Brazilian species, with descriptions, illustrations, geographic distribution, and specimens examined, was presented by Labiak and Prado (2003). Previously, seven species were recorded from Brazil (Labiak, 2003), most occurring in the Atlantic rainforest of southeastern and southern regions.

During a study carried out by JPSC in Itatiaia, we found a new species, which we describe here.

Ceradenia itatiaiensis Labiak \& Condack, sp. nov. TYPE: Brazil. Minas Gerais: Bocaina de Minas, Parque Nacional do Itatiaia, Alto dos Brejos, 1900 m, 31 Oct. 2004, J. P. S. Condack 308 \& E. Cortines (holotype, RB). Figure 1.
Haec species Ceradeniae albidulae (Baker) L. E. Bishop affinis, sed ab ea laminae foliaris segmentis setis marginalibus instructis distinguenda.

Rhizomes erect, radially symmetrical, scaly, the scales $0.3-0.4 \mathrm{~cm}$, golden brown, narrowly triangular, with short glands on the margin and scale surfaces. Fronds $7-14 \times 1-2 \mathrm{~cm}$, clustered, erect to slightly arching (fronds straight or curved); stipes $7-15 \times$ ca. $0.4 \mathrm{~mm}$, dark brown, terete, densely hirsute with castaneous setae, $1-1.5 \mathrm{~mm}$, and white glandular hairs, ca. $0.1 \mathrm{~mm}$, with 2 (rarely 3 ) enlarged globose apical cells; laminae pinnatisect, linear-lanceolate, membranaceous, abruptly tapered to the base with 1 or 2 proximal segments half the length of the middle ones, laminae gradually reduced at the apices; rachises visible in the proximal $1 / 3$ of the lamina on both sides, castaneous, not visible on both sides of the laminae from the middle to the distal $1 / 3$, gradually covered by greenish laminar tissue, lacking setae; segments 6-9 × 2.5-3.5 mm, deltate to linear-deltate, slightly oblique to the rachises, asymmetrical at the base, the margins slightly revolute, costae and veins obscure on both surfaces; indument of setae borne only on the laminar margins and glandular hairs on rachises, veins, and laminar tissue abaxially, setae similar to those on stipes; sinuses narrower than the segment width; veins simple or only the acroscopic basal ones furcate, ending near the laminar margin, 3 to 5 pairs per segment. Sori round, at vein apices, in 2 to 4 pairs per segment, disposed on the distal portion, not protruding beyond the lamina margins when mature, with glandular paraphyses, these with enlarged globose apical cells and shorter than the sporangia.

Distribution, ecology, and IUCN Red List category. Ceradenia itatiaiensis is epiphytic, occurring at about $1900 \mathrm{~m}$, known only from the mountains of Itatiaia. According to IUCN Red List criteria (IUCN, 2001), this species can be considered as Vulnerable (VU) because 


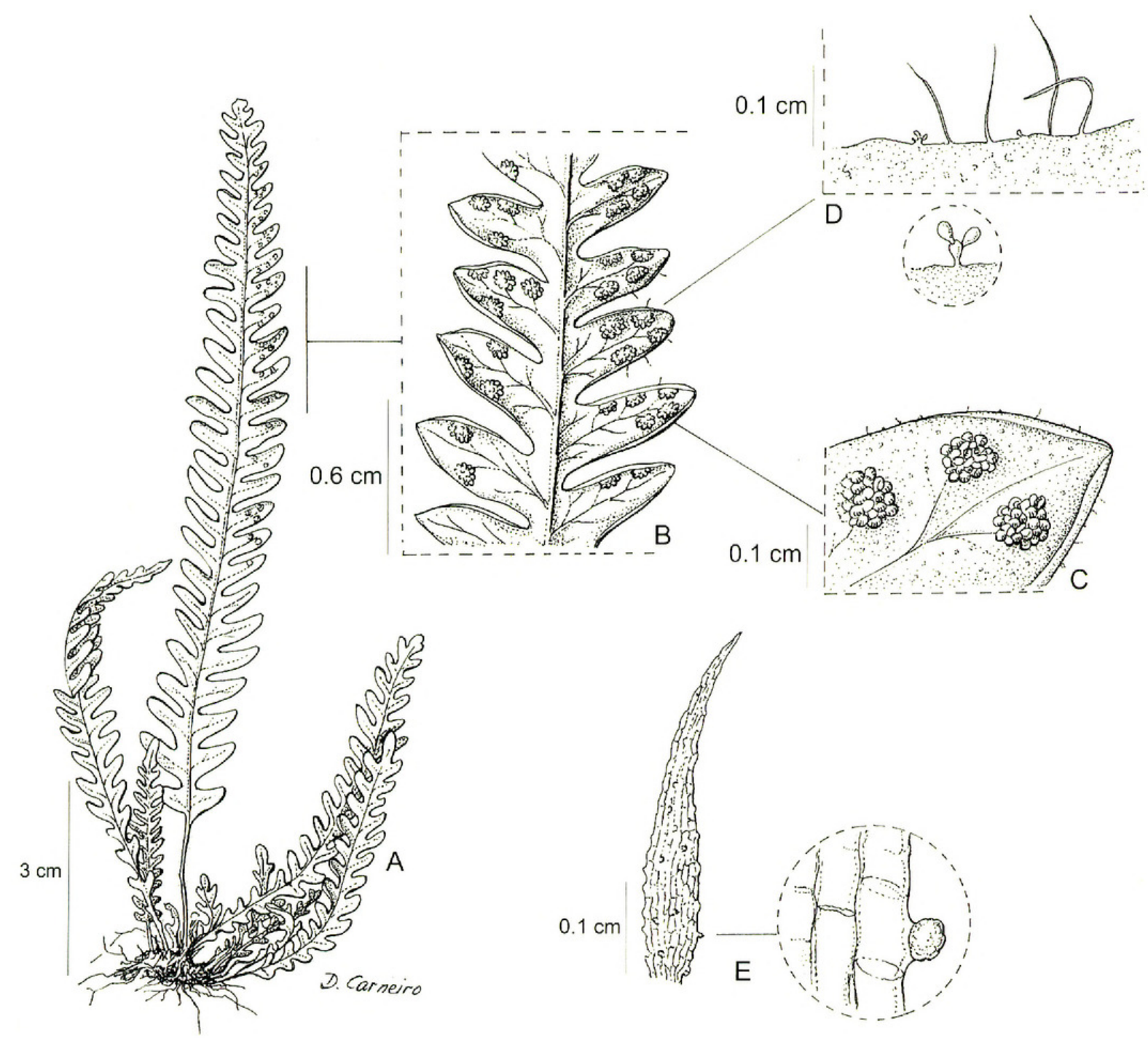

Figure 1. Ceradenia itatiaiensis Labiak \& Condack. — A. Habil. — B. Laminar detail. —C. Segment detail. —D. Selae and glandular trichomes on laminar margins. -E. Rhizome scale, with short marginal glands. Drawn from the holotype, Condack $308 \&$ Cortines (RB).

of its restricted area of occupancy and the apparent small number of individuals in nature.

Etymology. The specific epithet refers to the type locality.

Relationships. Ceradenia itatiaiensis is characterized by having linear-lanceolate, pinnatisect laminae; deltate to linear-deltate segments; often slightly revolute margins; basal segments half the length of the middle ones, not reduced to auricles; indument of castaneous setae on stipe and segment margins; and short glandular trichomes with two (rarely three) enlarged globose apical cells on margins and the abaxial side of the laminae. This species is most similar to C. albidula, and shares with this species the conspicuous glandular hairs on the abaxial laminae surface. However, $C$. albidula differs by the absence of setae on lamina margins and by its linear- lanceolate laminae, with basal segments often reduced to auricles. Ceradenia albidula is also endemic to southeastern Brazil, with a sympatric distribution with C. itatiaiensis. Both species occur at high elevations of the Serra do Mar, but $C$. itatiaiensis seems to be much more restricted in its distribution, whereas C. albidula is widely distributed in southeastern Brazil.

Paratype. BRAZIL. Minas Gerais: Bocaina de Minas, Parque Nacional do Itatiaia, Alto dos Brejos, $1900 \mathrm{~m}$, J. P. S. Condack, L. S. Sylvestre, C. S. Ramos \& D. Monteiro 548 (RB).

Acknowledgments. We thank Rafaela C. Forzza and Claudine Mynssen for PHL's research visit to RB herbarium, and Diana Carneiro for preparing the illustrations. This study was partially supported by Fundação Botânica Margaret Mee/Programa Mata Atlântica, which provided a master's scholarship for JPSC. We are also grateful to Alan R. Smith and 
Barbara Parris for their helpful comments on the manuscript.

\section{Literature Cited}

Bishop, L. E. 1988. Ceradenia, a new genus of Grammitidaceae. Amer. Fern J. 78: 1-5.

IUCN. 2001. IUCN Red List Categories and Criteria, Version 3.1. Prepared by the IUCN Species Survival Commission. IUCN, Gland, Switzerland, and Cambridge, United Kingdom.

Labiak, P. H. 2003. A new combination in the fern genus Ceradenia (Grammitidaceae). Kew Bull. 58: 991-994.
\& J. Prado. 2003. Grammitidaceae (Pteridophyta) no Brasil, com ênfase nos gêneros Ceradenia, Cochlidium e Grammitis. Hoehnea 30(3): 243-283.

Parris, B. S. 2002. New species and new combinations in African Grammitidaceae (Filicales). Kew Bull. 57: $423-434$.

2005. Grammitidaceae. Pp. 1-21 in H. J. Beentje \& C. M. Whitehouse (editors), Flora of Tropical East Africa. Royal Botanic Gardens, Kew.

Ranker, T. A., A. R. Smith, B. S. Parris, J. M. O. Geiger, C. H. Haufler, S. C. K. Straub \& H. Schneider. 2004. Phylogeny and evolution of grammitid ferns (Grammitidaceae): A case of rampant morphological homoplasy. Taxon 53: 415-428. 


\section{$2 \mathrm{BHL}$ Biodiversity Heritage Library}

Labiak, Paulo Henrique. 2008. "Ceradenia itatiaiensis, a new species of Polypodiaceae from southeastern Brazil." Novon a journal of botanical nomenclature from the Missouri Botanical Garden 18, 495-497.

View This Item Online: https://www.biodiversitylibrary.org/item/55381

Permalink: https://www.biodiversitylibrary.org/partpdf/58014

\section{Holding Institution}

Missouri Botanical Garden, Peter H. Raven Library

\section{Sponsored by}

Missouri Botanical Garden

\section{Copyright \& Reuse}

Copyright Status: In copyright. Digitized with the permission of the rights holder.

License: http://creativecommons.org/licenses/by-nc-sa/3.0/

Rights: https://biodiversitylibrary.org/permissions

This document was created from content at the Biodiversity Heritage Library, the world's largest open access digital library for biodiversity literature and archives. Visit BHL at https://www.biodiversitylibrary.org. 